\title{
Conservation importance of previously undescribed abundance trends: increase in loggerhead turtle numbers nesting on an Atlantic island
}

\author{
Jacques-Olivier Laloë, Jacquie Cozens, Berta Renom \\ Albert Taxonera and Graeme C. Hays
}

\begin{abstract}
For many species abundance data from across their entire range are incomplete, and therefore it is difficult to accurately assess their conservation status. Even for species that are large, charismatic and relatively easy to study, conservation assessments are often hampered by lack of data. Here we report a marked, previously undescribed, increase in numbers at a breeding colony of the loggerhead turtle Caretta caretta, a species that is Critically Endangered in several parts of its range, and place this report in the global context for this species. We present a 10-year (2008-2017) dataset of nesting activities for this species on the island of Sal, one of the Cape Verde islands in the Atlantic Ocean. Foot patrols recorded 21,938 nests during the study period. We estimate that the annual number of nests on Sal increased from 506 in 2008 to 7,771 in 2017. Taking into account that there are only two known loggerhead turtle rookeries (on Masirah Island, Oman, and in Florida, USA) with $>50,000$ nests reported annually, and few with $>1,000$ nests per year, our results suggest that Sal is one of the 10 largest loggerhead turtle rookeries globally. Our work highlights the conservation significance of reporting trends in abundance at breeding sites for marine turtles and other taxa.
\end{abstract}

Keywords Conservation policy, extinction, global assessments, IUCN Red List, loggerhead turtle, marine turtles, Regional Management Unit, threatened species

Supplementary material for this article is available at https://doi.org/10.1017/Soo30605318001497

\section{Introduction}

Tor many plant and animal species key ecological

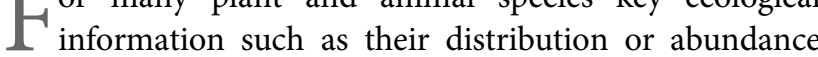

JaCQUes-Olivier LALOË (Corresponding author, (1) orcid.org/0000-0002-14371959) and Graeme C. Hays Centre for Integrative Ecology, Deakin University, Geelong, Australia. E-mail j.laloe@deakin.edu.au

Jacquie Cozens, Berta Renom* and Albert Taxonera* SOS Tartarugas, Santa Maria, Sal, Republic of Cape Verd

${ }^{*}$ Also at: Project Biodiversity, Santa Maria, Sal, Republic of Cape Verde

Received 8 August 2018. Revision requested 6 November 2018

Accepted 30 November 2018. First published online 16 September 2019. is lacking. For instance, one in six species assessed by the International Union for Conservation of Nature and Natural Resources (IUCN) is categorized as Data Deficient (IUCN, 2018). Assessing the global status of a species often relies on the collation of disparate datasets (e.g. Mazaris et al., 2017). In addition, species may be increasing in abundance in part of their range but decreasing elsewhere, driving regional conservation status assessments (e.g. Wallace et al., 2010). However, at both global and regional scales assessment quality is limited by the accuracy and completeness of the data available, and abundance estimates can be incomplete even for well-studied taxa (Mazaris et al., 2017). Lack of data can have profound conservation implications. Firstly, the conservation outlook for species with hitherto undescribed large and/or increasing populations can be more optimistic than previously believed. For example, a recently discovered breeding population of the Indochinese tiger Panthera tigris corbetti in eastern Thailand brought the total known number of breeding populations of this Critically Endangered subspecies to two (Reid, 2017). Secondly, negative population trends may be undescribed and the species' conservation outlook may be worse than previously suspected. For example, it was recently estimated that although there are more western lowland gorillas Gorilla gorilla gorilla than previously thought, their numbers are declining (Strindberg et al., 2018). Population abundance and trend data are essential for making informed conservation assessments at both local and global scales, and for guiding conservation management and policy. Marine turtles are amongst the taxa of conservation concern for which recent information on population trends is lacking for many parts of their global range. For example, in a review of published time series of global nesting trends Mazaris et al. (2017) identified time series for 299 rookeries, but data for 118 had not been updated since 2009. Even for areas where marine turtles are well-studied, there are few recent estimates of population trends. For example, although five marine turtle species nest in Australia in large numbers, time series extending beyond 2010 are only available for one species, the flatback turtle Natator depressus (Mazaris et al., 2017). In addition to a lack of recent datasets, the use of global assessments to establish the conservation status of individual marine turtle species has been widely debated in the scientific community because of regional variations in population trends (e.g. Mrosovsky, 2003; Godfrey \& 
Godley, 2008; Seminoff \& Shanker, 2008). To address such regional variations the Regional Management Units framework was proposed by Wallace et al. (2010) to improve understanding of the conservation status of marine turtles. Under this framework, marine turtle populations were grouped into units of protection by their biogeographical traits, including geographical distribution and genetic stock. Adopting this approach has helped direct research and conservation efforts through the identification of threats and data gaps (e.g. Wallace et al., 2011). In addition, the IUCN adopted this framework to assess the conservation status of marine turtle species (e.g. Casale \& Marco, 2015). At the time of writing, IUCN assessments at the scale of Regional Management Units were only available for the loggerhead turtle Caretta caretta (Supplementary Table 1) and for the leatherback turtle Dermochelys coriacea, but future assessments for other species are likely to also use this framework.

Ten Regional Management Units, many of which contain numerous nesting sites, have been defined for the loggerhead turtle (Wallace et al., 2010). The Northwest Atlantic Regional Management Unit, for example, encompasses nesting sites in nearly 40 countries in South, Central and North America (Ceriani \& Meylan, 2017). In contrast, other Regional Management Units contain few nesting sites. Within the Northeast Atlantic Regional Management Unit, the Cape Verde archipelago is the most important nesting site for loggerhead turtles (Casale \& Marco, 2015). Other nesting sites in this Management Unit are found along the Northwest African coast, but few data are available from these sites (Fretey, 2001, as cited in Casale \& Marco, 2015). Within Cape Verde, most data are from Boa Vista island and little is known about the number of nests on other islands of the archipelago (Casale \& Marco, 2015). At the time of the latest IUCN assessment for loggerhead turtles in the Northeast Atlantic Regional Management Unit, no information on the population trend was available because there are no time-series datasets with $>10$ years of data for the Regional Management Unit (Casale \& Marco, 2015).

Here we present the first 10-year dataset of loggerhead turtle nesting activities on Sal, an island in the Cape Verde archipelago, and report a major increase in nesting numbers that was previously undescribed. We highlight the importance of making abundance data available for wide-ranging species, so that conservation assessments can be improved and conservation priorities can be identified more effectively.

\section{Study area}

Cape Verde is an archipelago of 10 islands in the Northeast Atlantic, c. $600 \mathrm{~km}$ off West Africa. The $216 \mathrm{~km}^{2}$ island of Sal in the north-east (Fig. 1a) is relatively flat (Zazo et al., 2007), with a tropical-dry climate and scarce rain, even in
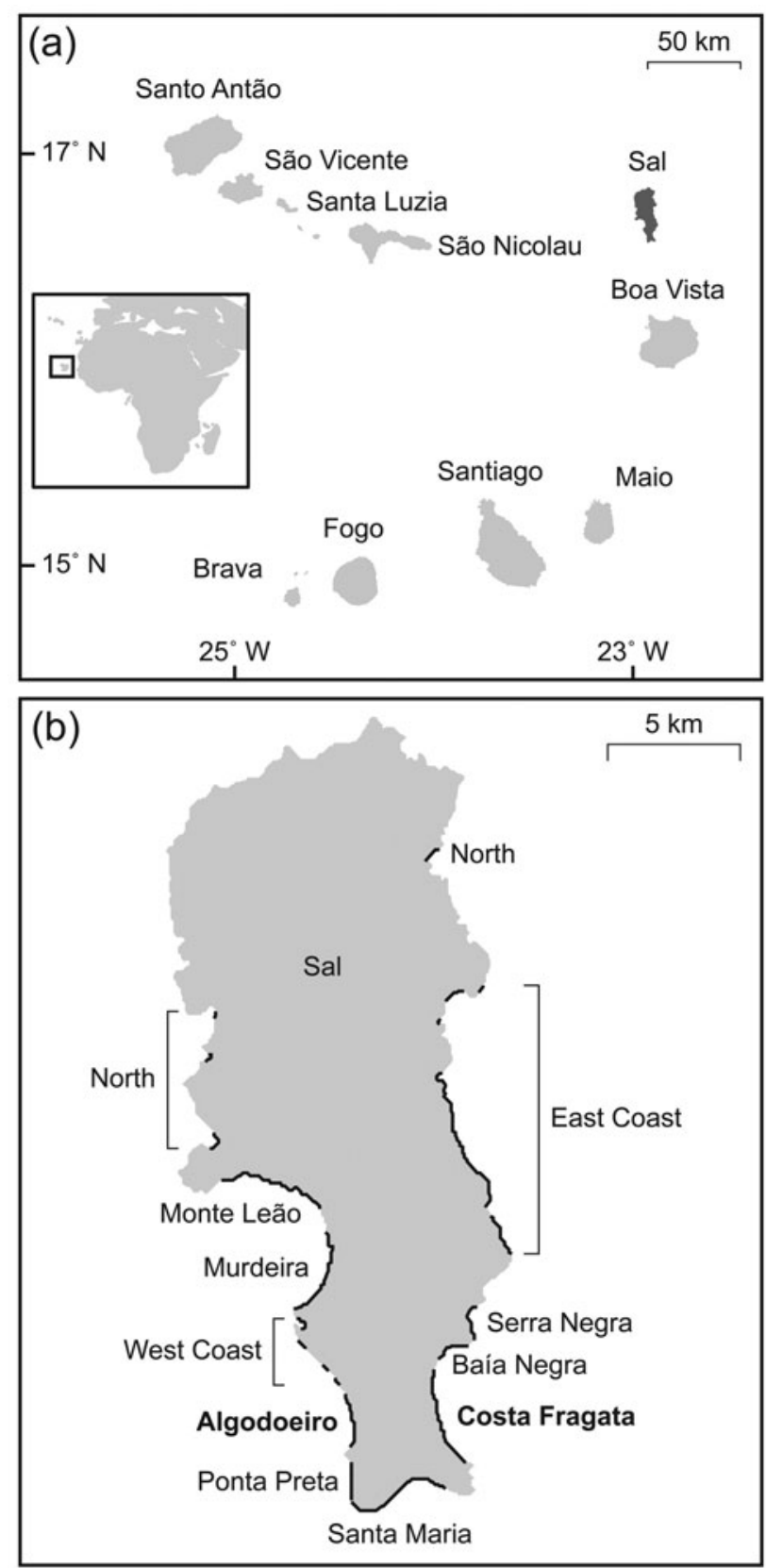

FIg. 1 Map of the study site. (a) Cape Verde lies in the north-east Atlantic c. $600 \mathrm{~km}$ off West Africa (inset map). Loggerhead turtles Caretta caretta nest on all islands of the archipelago (Marco et al., 2011). The island of Sal (dark grey) is situated in the north-east of the archipelago. (b) Location of loggerhead nesting beaches on Sal. Monitoring efforts were constant throughout the study period on Algodoeiro and Costa Fragata beaches, which were used as index beaches (indicated in bold).

the rainy season (Zazo et al., 2007). Beaches on the western coastline have rocky reefs close to the shore, whereas beaches on the eastern coastline lack offshore reefs. Beach sand varies from white, fine coral to dark, coarse volcanic sand. The southern and south-eastern coastlines are 
urbanized and new developments are planned (Taylor \& Cozens, 2010). Loggerhead turtles nest on beaches around the island, but with the majority of nesting in the south (Taylor \& Cozens, 2010).

\section{Methods}

\section{Monitoring of nesting activities}

Loggerhead turtles nest in Cape Verde during the warmer months of the year (June-October; Marco et al., 2012). We divided nesting beaches into sections (Supplementary Table 2) and conducted regular beach surveys during 2008-2017 to monitor nesting activities. To detect the first nesting activity of the season, we conducted morning surveys starting at sunrise daily, from early June onwards. After recording the first nesting activity, we carried out night surveys (20.00-06.00) on all nesting beaches until the end of the nesting season.

During surveys, observers walked along the high-water line and looked for turtles and turtle tracks on the beach. If a turtle was encountered, it was observed from a distance to assess whether or not she would nest. If turtle tracks were present, the observer looked for signs of nesting activity (e.g. presence of a body pit and sand spraying marks; Dodd, 1988) to establish if a clutch had been laid. Any tracks encountered during a survey were crossed out in the sand to prevent double-counting.

Turtle activities on the beaches were recorded as nesting when an egg clutch was laid, as so-called false crawls, during which a turtle emerged onto the beach and subsequently returned to the sea without attempting to dig an egg chamber, or as aborted nests, whereby a turtle emerged onto the beach, attempted to dig one or more egg chambers but returned to the sea without depositing a clutch of eggs. Any activities that could not be confirmed as nesting, false crawls or aborted nests were recorded as unconfirmed activities.

We always carried out morning surveys (starting at sunrise) after night surveys to ensure all nesting activities were recorded for each night. Monitoring of the nesting beaches continued for 10 consecutive nesting seasons during 2008-2017.

\section{Index beaches and surveys}

We were able to expand monitoring efforts during the study period as a result of increased funding. In the first years of monitoring (2008-2011), we conducted night surveys on three beaches, but extended this to six beaches during the final years (2014-2017) of the study period (Supplementary Table 2). Monitoring efforts were constant at two beaches, Algodoeiro and Costa Fragata (Fig. 1b), throughout the entire study period. These two beaches were used as index beaches.

In addition to regular morning and night surveys at the monitored beaches, we conducted additional surveys fortnightly during the nesting season. During these surveys all beaches that were not regularly monitored were surveyed in 1 day, with all encountered tracks being inspected, recorded and marked. These surveys started at 06.00 and ended when all beaches had been surveyed.

To estimate the total number of clutches laid annually since 2008 we had to consider the clutches deposited at those beach sections for which no data were collected during some years. For a conservative estimate, we divided the number of clutches laid at a given beach section in a given year by the number of clutches laid on the index beaches in the same year. We then used the minimum value of that ratio across all years to estimate the minimum number of clutches laid at a section in a year in which no data were collected. For example, no data were collected in 2008 for the Praia Chano beach section (Supplementary Table 2). During the years for which data were collected, this beach harboured $2-8 \%$ of the number of nests recorded on the index beaches, so we estimated that in 2008 this section contained at least $2 \%$ of the number of nests recorded on the index beaches in that year. We assumed that the ratio of nests to activities was constant throughout the study period and corrected the number of nests reported in years with outlying nests-to-activities ratios (Supplementary Table 3 ).

We followed the methodology of Mazaris et al. (2017) to calculate the annual rate of change in nest numbers. We used a linear regression model to examine whether there was a significant trend in nest numbers during the study period, and the non-parametric Mann-Kendall tau rank correlation test for additional confirmation.

\section{Global assessment of large loggerhead turtle rookeries}

We used the most recent IUCN assessment for loggerhead turtles (Casale \& Tucker, 2017) to identify the major loggerhead rookeries globally. For each site we searched the published literature to see if more recent data were available and checked the reference lists of relevant articles to locate additional sites documented since the IUCN assessment. We only included sites for which $>100$ nests had been reported annually. Nest numbers reported had mostly been counted directly or estimated from recorded turtle tracks. Where studies reported the annual number of nesting females we used clutch frequencies reported for those sites to estimate annual nest numbers. When local clutch frequencies were not available for a site we used clutch frequencies reported for the nearest rookery (Supplementary Table 4).

\section{Results}

\section{Nesting season and activities}

We recorded a total of 59,041 turtle activities on Sal island during 2008-2017. Of these, 21,938 (37\%) were nests, 23,285 


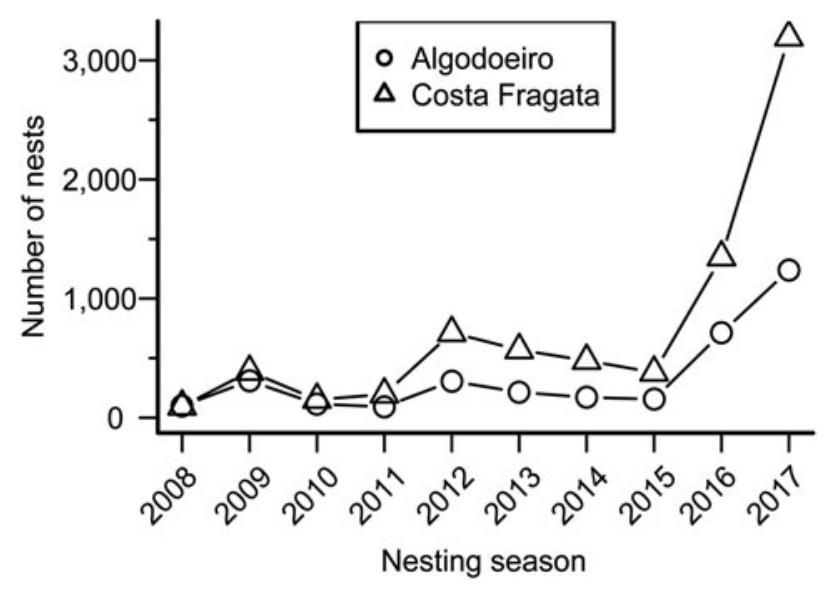

Fig. 2 Time series of the number of nests recorded on the index beaches Algodoeiro and Costa Fragata, where survey efforts were constant during 2008-2017.

(39\%) false crawls, 12,706 (22\%) aborted nests and 1,112 (2\%) unconfirmed activities.

The first clutch of the season was typically laid in mid June (median $=17$ June; interquartile range $=13$ days, 9-22 June) and the last nest of the season was typically in early November (median $=3$ November; interquartile range $=14$ days, 27 October-10 November). The nesting season lasted 127-186 days $($ median $=143$ days; interquartile range $=23$ days, 133-156 days).

\section{Number of nests on the index beaches}

We calculated the annual number of nests for each index beach during 2008-2017 (Fig. 2). Except for the first survey year, the number of nests on Costa Fragata was higher than on Algodoeiro throughout the study period and trends at both beaches were similar. During the last 2 years of the study period the number of nests increased considerably. Over the course of the study period, nest numbers increased from 98 and 95 to 1,239 and 3,194 on Algodoeiro and Costa Fragata, respectively.

In 2017, the final year of monitoring, the index beaches accounted for c. 57\% (Algodoeiro 16\% and Costa Fragata 41\%) of all recorded nests on Sal (Fig. 3). Six beaches had $<200$ recorded nests over the course of the 10-year period and three beaches (including the two index beaches) had $>1,000$ nests during the study period.

\section{Total number of nests on Sal island}

In the first 3 years of beach monitoring we probably underestimated the numbers of nests on the island. The ratio of nests to activities increased from 0.29 in 2010 to 0.38 in 2011 and remained relatively constant thereafter. The higher nests-to-activities ratio observed from 2011 onwards is probably the result of an increased ability to identify nests

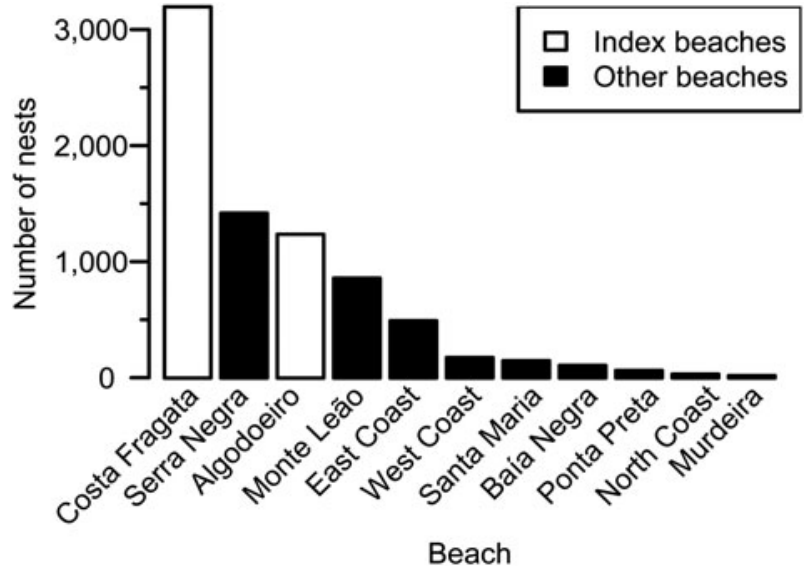

FIG. 3 Numbers of loggerhead turtle nests recorded on different study beaches in 2017 .

because of experience gained over several years of monitoring. We corrected the number of nests reported in 20082010 to account for this observed change in nesting success (Supplementary Table 3). However, a change in the assessment of nesting versus non-nesting activities alone does not account for the overall increase in the number of nests estimated over the study period.

The total number of nests on Sal increased from 506 to 7,771 during 2008-2017 (Fig. 4), mirroring the trend at the index beaches (Fig. 2), and the same significant increase is observed in the last 2 years of the study period.

The annual rate of change in nest numbers was $r=25 \%$ per year and the increase in nest numbers observed over 10 years is statistically significant (linear regression: $R^{2}=0.54$, $\mathrm{P}=0.015$; Mann-Kendall tau rank correlation test: $\mathrm{tau}=0.56$, $\mathrm{P}=0.032$ ).

Loggerhead turtles lay on average three to five clutches per breeding season on Boa Vista (Varo-Cruz et al., 2007). Using these values, we estimated that the number of females nesting on Sal was 100-200 in 2008 and 1,600-2,600 in 2017.

\section{Global assessment of large loggerhead turtle rookeries}

Loggerhead rookeries occur across the subtropical and temperate regions, with major nesting sites in the Atlantic, Indian and Pacific oceans and in the Caribbean and Mediterranean seas (Fig. 5). There are only two loggerhead turtle rookeries in the world in which reported nest numbers exceed 50,000 annually: Masirah Island in Oman (c. 65,000 nests/year; Tucker et al., 2013, as cited in Casale, 2015) and Florida in the USA (c. 73,000 nests/year; Richards et al., 2011). There are few sites with $>1,000$ annual loggerhead turtle nests; these include Australia, Brazil, Greece, Japan, South Africa, Turkey and the USA (Fig. 5). With 7,771 nests reported in the 2017 nesting season, Sal is therefore one of the 10 largest loggerhead turtle rookeries globally (Supplementary Table 4). 


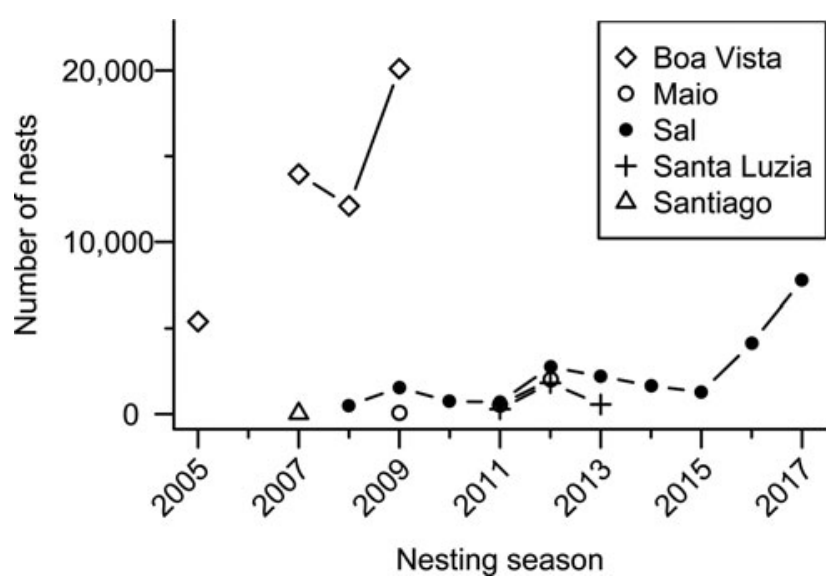

FIG. 4 Total number of loggerhead nests reported in Cape Verde during 2005-2017. Data for Sal are from this study. Data were available for Boa Vista (López-Jurado, 2007; Marco et al., 2012), Maio (Cozens et al., 2011; Martins et al., 2013), Santa Luzia (Rocha et al., 2015) and Santiago (Loureiro, 2008). Data points connected by a line originate from the same study.

Using data extending to 2015, the global annual number of loggerhead turtle nests was estimated to be just over 200,000, and the Northeast Atlantic Regional Management Unit (which encompasses Cape Verde) accounted for $7.5 \%$ of this value at the time (Ceriani \& Meylan, 2017).

\section{Discussion}

Our key finding of a hitherto undescribed increase in nesting numbers for a major breeding population of a threatened species may have important broad implications for conservation biology. It is perhaps surprising for a group as iconic and charismatic as marine turtles that a significant trend in abundance may go unreported, considering that nesting activities are clearly evident from large, visible tracks left on beaches. This lack of reporting could be a result of marine turtles often nesting in remote or undeveloped areas, a trait shared with a range of threatened species in both terrestrial and aquatic environments. However, even when data are available they are often not reported in the public domain. For example, Mazaris et al. (2017) reported that abundance time series for many sites have not been updated in the last decade. This lack of recent published data highlights a need for census data to be made available, so that regional and global conservation status assessments can be based on more robust evidence. Our study makes an important contribution in this respect.

The earliest census for loggerhead turtles on Sal dates from 2008 and estimated the annual number of nests to be $<500$ (Cozens et al., 2009, as cited in Marco et al., 2011). In the following year 1,071 nests were counted on the entire island during the nesting season (Lino et al., 2010). With the latest annual nesting numbers exceeding
7,500, our results indicate that the island of Sal is an important nesting site for this species. Within Cape Verde, Boa Vista is the most important nesting site, with 12,00020,000 nests annually (Marco et al., 2012). Recently, annual nest numbers for the whole archipelago were estimated to be 43,500 (Inforpress, 2018), indicating that the Northeast Atlantic Regional Management Unit is the third most important Regional Management Unit for the loggerhead turtle globally (Marco et al., 2012; Supplementary Table 4). Based on these estimates, Cape Verde currently hosts c. 20\% of the world's adult loggerhead turtle population.

We used annual nest numbers as an indication of the annual number of nesting turtles at our study site. However, annual nest numbers can vary over time for several reasons (e.g. the number of clutches laid by a female can fluctuate between breeding seasons, and the distribution of reproductive efforts varies across different nesting sites), so annual nest numbers may not reflect overall marine turtle populations dynamics (NALWG, 2018). In addition, the number of nesting turtles is only one measure of population size and does not include all individuals in a population. Adult males are essential for population viability and may become gradually more important if hatchling production becomes increasingly female-biased as a result of temperature-dependent sex determination combined with warmer incubation conditions, which can be expected with ongoing climate change (Hays et al., 2014; Esteban et al., 2016).

Marine turtle population trends are routinely estimated using annual nest numbers (e.g. Casale \& Tucker, 2017), and nesting populations are often estimated by dividing the number of nests by clutch frequency. Similarly, nest numbers are often estimated by multiplying nesting population size by clutch frequency. Because clutch frequency can vary amongst populations, population-specific clutch frequency values should be used for robust population estimates. If a population-specific clutch frequency is not available, the clutch frequency from another population can be used, but this will reduce the accuracy of the resulting estimate. In addition, clutch frequencies tend to be underestimated by foot patrols compared to newer techniques such as using satellite tags to record each time a female nests (Esteban et al., 2017). Future studies may refine mean clutch frequency estimates and hence improve information on the number of nesting turtles. Despite these methodological limitations, our key conclusion that the Cape Verde islands host a large number of nesting loggerhead turtles remains robust.

As outlined in the 2015 IUCN assessment of the loggerhead turtle's status, more data are needed to assess the population trend for the Northeast Atlantic Regional Management Unit (Casale \& Marco, 2015). Here we offer some insight, using nest numbers as a proxy for population size. We report a 15 -fold increase of nest numbers over a 10 -year period. The observed rate of change in nest number 


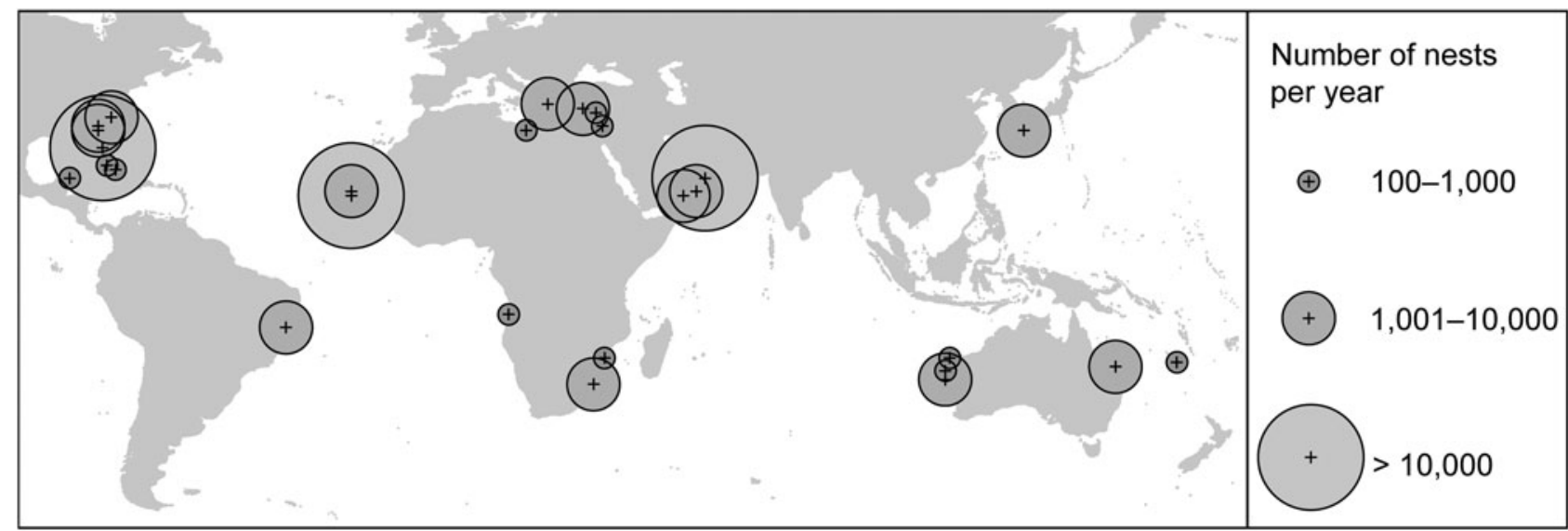

FIG. 5 Location and size of the major loggerhead rookeries globally ( $>100$ nests reported annually). Plot symbol size reflects rookery size measured in annual nest numbers. For data sources, see Supplementary Table 4.

of $25 \%$ per year is at the high end of the range reported in other studies (ranging from c. $-21 \%$ to $39 \%$ per year; Mazaris et al., 2017). The reasons behind this dramatic increase in nest numbers are uncertain but increases in marine turtle nest numbers have been linked to the implementation of successful conservation measures in some locations (e.g. Marcovaldi \& Chaloupka, 2007). In the US Virgin Islands in the Caribbean Sea, a large increase (c. $13 \%$ per year) in the annual number of leatherback turtle nests was explained by a major conservation effort to protect eggs and so increase the number of hatchlings entering the sea (Dutton et al., 2005). However, if increased hatchling survival is the reason underlying an increase in nesting numbers, then we would expect a delay between the start of conservation measures and the rise in nesting numbers because hatchlings take many years to reach sexual maturity and return to nest. Loggerhead turtles may only mature after 45 years (Scott et al., 2012), so the marked increase in nest numbers that we reported may reflect an increase in hatchling success prior to the instigation of targeted conservation.

Alternatively, a reduction in the offtake of nesting adults while they are ashore or a reduction in catch rates of turtles at sea may be contributing to the increasing nest numbers. Nesting females were historically hunted in Cape Verde (Marco et al., 2011) and consumption of marine turtle meat continues despite national and international laws to protect marine turtles (Marco et al., 2012). Presence of surveyors on the beach during night surveys effectively deters turtle hunters on Sal, with lower mortality being observed on surveyed beaches vs unsurveyed beaches (Lino et al., 2010). Protection of nesting beaches has resulted in a significant reduction in the number of turtles being killed on Sal (B. Renom \& A. Taxonera, unpubl. data spanning 7 years), highlighting the value of beach protection through the implementation of night surveys and illustrating how a reduction in adult catch rate can contribute to an increase in nest numbers.
Future studies may be able to identify variables that have contributed to the increase in nest numbers on Sal. For example, although the trends in nest numbers at the index beaches were similar, the increase was more pronounced on Costa Fragata than on Algodoeiro (Fig. 2). Biophysical differences between the two beaches, such as orientation (west vs east), exposure (sheltered vs exposed) or sand colour (dark vs light; Laloë et al., 2014) could contribute to the differences in the numbers of nests observed at these beaches. Additionally, new developments have been built along the south-western coastline, including along parts of Algodoeiro, and light pollution has increased on this index beach. Light pollution affects nest site selection in loggerhead turtles (Price et al., 2018), and may have resulted in turtles preferring to nest on the more secluded beaches.

Because marine turtles exhibit temperature-dependent sex determination, with females produced at higher temperatures, a long-term rise in sand temperatures (over multiple decades) could also have contributed to an increase in the number of female hatchlings and consequently in the number of nesting females (Laloë et al., 2014; Hays et al., 2017). Population modelling could help identify the processes contributing to the increase in nesting numbers (Chaloupka, 2002; Dutton et al., 2005; Stewart et al., 2011).

Our results give cause for cautious optimism, with a sizable population ( $>1,000$ nesting females) and an increasing trend in nest numbers observed on Sal. However, threats to turtles remain, as on other islands of the archipelago, and conservation management needs to continue. Threats to turtles in Cape Verde include the ongoing hunting of adult nesting females for consumption (Marco et al., 2011, 2012), bycatch of turtles in longline fisheries (Melo \& Melo, 2013), predation of eggs by the ghost crab Ocypode cursor (Marco et al., 2015), coastal development on the beachfront and light pollution (Taylor \& Cozens, 2010; Marco et al., 2018). Climate change can also have detrimental effects on marine turtles, for example through sea level 
rise and beach erosion (Hamann et al., 2013; Varela et al., 2018), and higher temperatures can lead to female-biased sex ratios and increased nest failures (Laloë et al., 2017). At some sites in other locations, long-term increases in the number of nests at rookeries have been followed by longterm declines (Mazaris et al., 2017; NALWG, 2018), and the increases in nesting numbers that we report should therefore be used to drive continued marine turtle conservation and surveying efforts in the Cape Verde islands, to help ensure the long-term conservation of this important loggerhead turtle population.

Our findings highlight the value of long-term monitoring efforts and the importance of making abundance data available to improve conservation assessments. Lack of data can have profound implications for conservation management, and we encourage others working with marine turtles or different taxa to make their data available for conservation assessments.

Acknowledgements The authors thank SOS Tartarugas and Project Biodiversity for their ongoing conservation work, the numerous volunteers who helped with data collection, and two anonymous reviewers for their critiques. J-OL received funding for fieldwork from the Alasdair Downes Marine Conservation Fund and from the Society for Experimental Biology.

Author contributions Study conception: all authors; data collection: JC, BR, AT; data analysis: J-OL; writing: J-OL, GCH; revision: all authors.

\section{Conflicts of interest None.}

Ethical standards This research abided by the Oryx guidelines on ethical standards, was endorsed by the Ministry of Agriculture and Environment of Cape Verde through authorizations issued by the National Directorate of the Environment (permit number 24/2017) and complied with all relevant local and national legislation.

\section{References}

Casale, P. (2015) Caretta caretta (North West Indian Ocean subpopulation). In The IUCN Red List of Threatened Species. IUCN, Gland, Switzerland. Https://www.iucnredlist.org/details/84127873/o [accessed 12 March 2019].

Casale, P. \& Marco, A. (2015) Caretta caretta (North East Atlantic subpopulation). In The IUCN Red List of Threatened Species. IUCN, Gland, Switzerland. Http://www.iucnredlist.org/details/83776383/o [accessed 12 March 2019].

Casale, P. \& Tucker, A.D. (2017) Caretta caretta. In The IUCN Red List of Threatened Species. IUCN, Gland, Switzerland. Https://www. iucnredlist.org/species/3897/119333622 [accessed 12 March 2019].

Ceriani, S.A. \& Meylan, A.B. (2017) Caretta caretta (North West Atlantic subpopulation). In The IUCN Red List of Threatened Species. IUCN, Gland, Switzerland. Http://www.iucnredlist.org/ details/84131194/o [accessed 12 March 2019].

Chaloupka, M. (2002) Stochastic simulation modelling of southern Great Barrier Reef green turtle population dynamics. Ecological Modelling, 148, 79-109.
Cozens, J., Pereira, M., Mendes, E. \& Miles, R. (2009) First ever population census of nesting loggerheads on Sal island, Cape Verde. In Proceedings of the Twenty-Ninth Annual Symposium on Sea Turtle Biology and Conservation (eds L. Belskis, M. Frick,

A. Panagopoulou, A. Rees \& K. Williams), p. 29. National Oceanic and Atmospheric Administration, Miami, USA.

Cozens, J., Taylor, H. \& Gouveia, J. (2011) Nesting activity of the loggerhead sea turtle Caretta caretta (Linnaeus, 1758) on Maio, Cape Verde Islands. Zoologia Caboverdiana, 2, 62-70.

DodD, C.K. (1988) Synopsis of the Biological Data on the Loggerhead Sea Turtle Caretta caretta (Linnaeus 1758). United States Fish and Wildlife Service Biological Report 88. U.S. Fish and Wildlife Service, Washington, DC, USA.

Dutton, D.L., Dutton, P.H., Chaloupka, M. \& Boulon, R.H. (2005) Increase of a Caribbean leatherback turtle Dermochelys coriacea nesting population linked to long-term nest protection. Biological Conservation, 126, 186-194.

Esteban, N., Laloë, J.-O., Mortimer, J.A., Guzman, A.N. \& Hays, G.C. (2016) Male hatchling production in sea turtles from one of the world's largest marine protected areas, the Chagos Archipelago. Scientific Reports, 6, 20339.

Esteban, N., Mortimer, J.A. \& Hays, G.C. (2017) How numbers of nesting sea turtles can be overestimated by nearly a factor of two. Proceedings of the Royal Society B, 284, 20162581.

Fretey, J. (2001) Biogeography and Conservation of Marine Turtles of the Atlantic Coast of Africa. Convention on Migratory Species, Bonn, Germany.

Godfrey, M.H. \& Godley, B.J. (2008) Seeing past the red: flawed IUCN global listings for sea turtles. Endangered Species Research, 6, 155-159.

Hamann, M., Fuentes, M.M.P.B., Ban, N.C. \& Mocellin, V.J.L. (2013) Climate change and marine turtles. In The Biology of Sea Turtles: Volume 3 (eds J. Wyneken, K.J. Lohmann \& J.A. Musick), pp. 353-378. CRC Press, Boca Raton, USA.

Hays, G.C., Mazaris, A.D. \& Schofield, G. (2014) Different male vs. female breeding periodicity helps mitigate offspring sex ratio skews in sea turtles. Frontiers in Marine Science, 1, 43.

Hays, G.C., Mazaris, A.D., Schofield, G. \& Laloë, J.-O. (2017) Population viability at extreme sex-ratio skews produced by temperature-dependent sex determination. Proceedings of the Royal Society B, 284, 20162576.

Inforpress (2018) Cabo Verde Registou 43.50o Ninhos de Tartarugas Marinhas Durante o Ano de 2017-Rede Taola. Http://www.inforpress. publ.cv/maio-cabo-verde-registou-43-mil-e-quinhentos-ninhos-detartarugas-marinhas-durante-o-ano-de-2017-taola [accessed August 2018].

IUCN (2018) The IUCN Red List of Threatened Species v. 2017.3. Http:// www.iucnredlist.org [accessed August 2018].

Joppa, L.N., Roberts, D.L., Myers, N. \& Pimm, S.L. (2011) Biodiversity hotspots house most undiscovered plant species. Proceedings of the National Academy of Sciences of the United States of America, 108, 13171-13176.

Lalö̈, J.-O., Cozens, J., Renom, B., Taxonera, A. \& Hays, G.C. (2014) Effects of rising temperature on the viability of an important sea turtle rookery. Nature Climate Change, 4, 513-518.

Laloë, J.-O., Cozens, J., Renom, B., Taxonera, A. \& Hays, G.C. (2017) Climate change and temperature-linked hatchling mortality at a globally important sea turtle nesting site. Global Change Biology, 23, 4922-4931.

Lino, S.P.P., Gonçalves, E. \& Cozens, J. (2010) The loggerhead sea turtle (Caretta caretta) on Sal Island, Cape Verde: nesting activity and beach surveillance in 2009. Arquipélago: Life and Marine Sciences, 27, 59-63. 
López-Jurado, L.F., Sanz, P. \& Abella, E. (2007) Loggerhead nesting on Boa Vista, República de Cabo Verde. In SWOT Report: Volume 2 (eds R.B. Mast, L.M. Bailey \& B.J. Hutchinson), pp. 24-25. State of the World's Sea Turtles, Arlington, USA.

Loureiro, N.S. (2008) Sea turtles in Santiago Island, Cape Verde. Marine Turtle Newsletter, 120, 6-8.

Marco, A., Abella Pérez, E., Monzón Argüello, C., Martins, S., Araujo, S. \& López Jurado, L.F. (2011) The international importance of the archipelago of Cape Verde for marine turtles, in particular the loggerhead turtle Caretta caretta. Zoologia Caboverdiana, 2, 1-11.

Marco, A., Abella, E., Liria-Loza, A., Martins, S., López, O., JiméneZ-Bordón, S. et al. (2012) Abundance and exploitation of loggerhead turtles nesting in Boa Vista island, Cape Verde: the only substantial rookery in the eastern Atlantic. Animal Conservation, 15, 351-360.

Marco, A., da Graça, J., García-Cerdá, R., Abella, E. \& Freitas, R. (2015) Patterns and intensity of ghost crab predation on the nests of an important endangered loggerhead turtle population. Journal of Experimental Marine Biology and Ecology, 468, 74-82.

Marco, A., Abella, E., Martins, S., López, O. \& PatinoMartinez, J. (2018) Female nesting behaviour affects hatchling survival and sex ratio in the loggerhead sea turtle: implications for conservation programmes. Ethology Ecology and Evolution, 30, 141-155.

Marcovaldi, M.Â. \& ChaloupKa, M. (2007) Conservation status of the loggerhead sea turtle in Brazil: an encouraging outlook. Endangered Species Research, 3, 133-143.

Martins, S., Soares, F., Abella, E., Koenen, F. \& Marco, A. (2013) Importance of the Island of Maio (Cape Verde) for current and future loggerhead conservation in the Eastern Atlantic. In Proceedings of the Thirty-Third Annual Symposium on Sea Turtle Biology and Conservation (eds T. Tucker, L. Belskis, A. Panagopoulou, A. Rees, M. Frick, K. Williams, R. LeRoux \& K. Stewart), p. 106. NOAA Technical Memorandum, Baltimore, USA. MAY, RM. (1988) How many species are there on Earth? Science, 241, 1441-1449.

Mazaris, D., Schofield, G., Gkazinou, C., Almpanidou, V. \& Hays, G.C. (2017) Global sea turtle conservation successes. Science Advances, 3, e1600730.

Melo, J. \& Melo, T. (2013) Interviews with fishers suggest European longlining threatens sea turtle populations in Cape Verdean waters. Marine Turtle Newsletter, 138, 18.

Meyer, C., Kreft, H., Guralnick, R. \& Jetz, W. (2015a) Global priorities for an effective information basis of biodiversity distributions. Nature Communications, 6, 8221.

Meyer, M.J., Vanhoorne, B. \& Appeltans, W. (2015b) Conservation of biodiversity through taxonomy, data publication, and collaborative infrastructures. Conservation Biology, 29, 1094-1099.

Mrosovsky, N. (2003) Predicting Extinction: Fundamental Flaws in IUCN's Red List System, Exemplified by the Case of Sea Turtles. Http://members.seaturtle.org/mrosovsky [accessed August 2018].

NALWG (Northwest Atlantic Leatherback Working Group) (2018) Northwest Atlantic Leatherback Turtle (Dermochelys coriacea) Status Assessment. WIDECAST Technical Report No. 16. Conservation Science Partners and the Wider Caribbean Sea Turtle Conservation Network (WIDECAST), Godfrey, USA.

Price, J.T., Drye, B., Domangue, R.J. \& Paladino, F.V. (2018) Exploring the role of artificial lighting in loggerhead turtle (Caretta caretta) nest-site selection and hatchling disorientation.

Herpetological Conservation and Biology, 13, 415-422.

ReID, V. (2017) Biodiversity news. Biodiversity, 18, 35-40.

Richards, P.M., Epperly, S.P., Heppell, S.S., King, R.T., Sasso, C.R., Moncada, F. et al. (2011) Sea turtle population estimates incorporating uncertainty: a new approach applied to western North Atlantic loggerheads Caretta caretta. Endangered Species Research, $15,151-158$.

Rocha, P.R., Melo, T., Rebelo, R. \& Catry, P. (2015) A significant nesting population of loggerhead turtles at the nature reserve of Santa Luzia, Cabo Verde. Chelonian Conservation and Biology, 14, 161-166.

Scott, R., MARSh, R. \& HAYs, G.C. (2012) Life in the really slow lane: loggerhead sea turtles mature late relative to other reptiles. Functional Ecology, 26, 227-235.

Seminoff, J. \& Shanker, K. (2008) Marine turtles and IUCN Red Listing: a review of the process, the pitfalls, and novel assessment approaches. Journal of Experimental Marine Biology and Ecology, $356,52-68$.

Stewart, K., Sims, M., Meylan, A., Witherington, B., Brost, B. \& CROWDER, L.B. (2011) Leatherback nests increasing significantly in Florida, USA; trends assessed over 30 years using multilevel modeling. Ecological Applications, 21, 263-273.

Strindberg, S., Maisels, F., Williamson, E.A., Stephen, B., Stoкes, E.J., Ав ' 'A, R. et al. (2018) Guns, germs, and trees determine density and distribution of gorillas and chimpanzees in Western Equatorial Africa. Science Advances, 4, eaar2964.

TAylor, H. \& Cozens, J. (2010) The effects of tourism, beachfront development and increased light pollution on nesting loggerhead turtles Caretta caretta (Linnaeus, 1758) on Sal, Cape Verde Islands. Zoologia Caboverdiana, 1, 100-111.

Tucker, A.D., Baldwin, R., Willson, A., Al-Kiyumi, A., Schroeder, B., Possardt, E. \& Witherington, B. (2013) Preliminary estimates for loggerhead clutch frequency from Masirah, Oman derived from satellite tracking. In Proceedings of the 33 rd Annual Symposium on Sea Turtle Biology and Conservation (eds T. Tucker, L. Belskis, A. Panagopoulou, A. Rees, M. Frick, K. Williams, R. Leroux \& K. Stewart), p. 243. National Oceanic and Atmosphere Administration, Miami, USA.

Varela, M.R., Patrício, A.R., Anderson, K., Broderick, A.C., DeBell, L., Hawkes, L.A. et al. (2018) Assessing climate change associated sea level rise impacts on sea turtle nesting beaches using drones, photogrammetry and a novel GPS system. Global Change Biology, 25, 753-762.

Varo-Cruz, N., Cejudo, D. \& López-Jurado, L.F. (2007) Reproductive biology of the loggerhead turtle (Caretta caretta L. 1758) on the island of Boa Vista (Cape Verde, West Africa). In Marine Turtles: Recovery of Extinct Populations (eds L.F. LópezJurado \& A. Liria), pp. 127-144. Canary Institute of Marine Sciences, Las Palmas, Canary Islands.

Wallace, B.P., Dimatteo, A., Hurley, B.J., Finkbeiner, E.M, Bolten, A.B., Chaloupka, M.Y. et al. (2010) Regional management units for marine turtles: a novel framework for prioritizing conservation and research across multiple scales. PLOS ONE, 5, e15465.

Wallace, B.P., Dimatteo, A., Bolten, A.B., Chaloupka, M.Y., Hutchinson, B.J., Abreu-Grobois, F.A. et al. (2011) Global conservation priorities for marine turtles. PLOS ONE, 6, e24510.

Zazo, C., Goy, J.L., Dabrio, C.J., Soler, V., Hillaire-Marcel, C., Ghaleb, B. et al. (2007) Quaternary marine terraces on Sal Island (Cape Verde archipelago). Quaternary Science Reviews, 26, 876-893. 